\title{
Men-centered Approaches for Primary and Secondary Prevention of HIV/ AIDS: A Scoping Review of Effective Interventions
}

\author{
Jalila Jbilou*, Steven S Robertson, Homayoon Jazebizadeh, Lise Gallant, Mark Robinson, Sarah Pakzad and Gilles Tremblay
}

Université de Moncton, Moncton, New Brunswick, Canada

\begin{abstract}
Approximately 65,000 people live with HIVIAIDS (PLWHA) in Canada and around $82 \%$ of declared cases $(52,932$ cases) of HIV and AIDS are men. Without evidence-based specific interventions, HIV will continue to spread. This scoping review aims to identify evidence on best practice programs for sexual and reproductive health promotion (i.e. HIVIAIDS) targeting men, and to document the best channels for reaching men. English and French language literature indexed in relevant electronic databases was systematically searched. This was complemented by a manual search through five periodicals specializing in men's health. A total of 6608 articles were identified and 39 articles that met all inclusion and exclusion criteria were retained in the synthesis. Three reviewers independently extracted information on: health topic (i.e. HIVIAIDS), design of services (structure and resources), modes of delivery, content of intervention and main outcomes. The preventive practices with the strongest supportive evidence included, just in time information available through electronic channels (website or cell phone). Interventions designed for men only, showed significantly greater effectiveness compared to interventions targeting both men and women. We derived practical recommendations to design an integrated evidence-based preventive intervention targeting men.
\end{abstract}

Keywords: Men's health; HIV/AIDS prevention; Best practices; Prevention interventions; Scoping review

\section{Introduction}

High rates of Human Immunodeficiency Virus (HIV) infection and Acquired Immune Deficiency Syndrome (AIDS) have become a significant issue of global concern, particularly the rates of such infection amongst men [1]. In Canada, the rate of positive HIV test reports is 7.6 per 100,000 . At the national level, the trend in annual HIV case reports since 1996 showed a steady decrease in the number of reported cases to the year 2000. This was followed by an overall increase through to 2008 , at which time the number of positive HIV test reports reached a high of 2,619. In 2011, 2,221 new adult cases ( $\geq 15$ years) were reported showing a slight decrease. In terms of sex and age distribution, among these $2,221,76.7 \%$ were men with a higher proportion of case reports among the $40-49$ year olds (27.1\% of male cases vs. $21.6 \%$ of female cases), followed by those over the age of 50 (M: $20.9 \%$ vs. F: $14.0 \%$ ) [2]. Overall, when looking at the different risk exposure categories for HIV, men who have sex with men (MSM) is still the leading reported exposure category in Canada; this is followed by heterosexual contact and injection drug use. There emergence of the HIV epidemic among MSM is likely due in part to a shift inperception, from viewing HIV as a terminal illness to viewing HIV as a chronic, manageable condition and a resulting sense of complacency related to HIV prevention behaviors [3]. However, the pattern of risk exposure differs by province/territory as well as by other health determinants (i.e. behavioral, social and biological factors). In fact, there are important differences between men and women in the physical mechanisms, as well as in socio-economic factors and consequences associated with HIV/AIDS infection. These stem from biology, risky behaviors and socially constructed gender differences between men and women, as well as utilization and access to timely and accurate healthcare and social resources. For example, distinct differences are observed between men and women in terms of age at diagnosis of HIV and AIDS. MSM received public health nursing care less frequently than youth and women who have sex with men [4]. Men tend to be diagnosed at an older age (compared to women) with MSM being the leading reported risk factor followed by heterosexual contact and injection drug use.
These specifically gendered epidemiological patterns of infection challenge both public health strategies and primary care services in how they can most effectively target the prevention of HIV/AIDS, especially when we know that: (1) the PHAC estimates that $25 \%$ of the $71,300(58,600$ to 84,000$)$ people living with HIV/AIDS in Canada were unaware of their infection (due to a lack of testing and/or diagnosis) and (2) the percentage distribution of positive HIV test reports among adult men ( $\geq 15$ years) by heterosexual contact exposure and year of test increased from $16.3 \%$ in 2004 to $20.4 \%$ in 2011 [2]. These two major statistics can be partly explained by the failure of standard populationbased preventive interventions to raise HIV awareness among the male population. MSM account for $23 \%$ of HIV/AIDS risk factors (i.e. risky sexual behaviors) for Canadians aged 15 and older [5]. Although MSM have high HIV/AIDS incidence and prevalence rates [6], this trend is changing and there is limited evidence on how best to face the challenge and be proactive in reducing infection amongst not only this group but also amongst other groups of men [7]. There is currently a focus in the literature on specific populations such as MSM, gay men and HIV positive men yet few prevention options that focus on other men. Given all that, some men may respond better to personal followup, while others may be more sensitive to group, computer-based or community based interventions [8-10], thus there is an urgent need for evidence-based multifaceted preventive strategies. In short, there is limited evidence that the HIV epidemic will be adequately addressed

${ }^{*}$ Corresponding author: Jalila Jbilou, Université de Moncton, Campus de Moncton, Pavillon Léopold-Taillon, 18, avenue Antonine-Maillet, Moncton NB, Canada E1A 3E9, Tel: 1(506)-858-4936; Fax: 1(506) 863-2284; E-mail: Jalila.jbilou@umoncton.ca

Received August 27, 2013; Accepted October 30, 2013; Published November 03, 2013

Citation: Jbilou J, Robertson SS, Jazebizadeh H, Gallant L, Robinson M, et al. (2013) Men-centered Approaches for Primary and Secondary Prevention of HIVI AIDS: A Scoping Review of Effective Interventions. J AIDS Clin Res 4: 257. doi: 10.4172/2155-6113.1000257

Copyright: @ 2013 Jbilou J, et al. This is an open-access article distributed under the terms of the Creative Commons Attribution License, which permits unrestricted use, distribution, and reproduction in any medium, provided the original author and source are credited. 
in Canada or the United States in the near future because both countries have concentrated epidemics, and many prevention intervention strategies are not tailored to the needs of what should be the priority populations within the two countries [4].

In New-Brunswick, a small rural Canadian province of 750,000 habitants and one of the Atlantic provinces, between 1985-2006, the percentage of all declared cases of HIV infection and AIDS among people age 15 and older was $88 \%$ (HIV) and 91\% (AIDS) in men compared with $12 \%$ (HIV) and $9 \%$ (AIDS) in women [11]. Despite the fact that in New Brunswick, the rate of positive HIV test new reports per 100,000 population is one of the lowest ones in Canada, there has been a significant increase from 0.6 in 2009 to 1.4 in 2011 [2]. To better understand the New Brunswick (NB) local context, one has to know that some social issues, such as illiteracy (more than 66\% have not reached Level 3 literacy, the minimum level required to function in Canadian society) and disadvantaged economic status (an unemployment rate around $11 \%$ ), are prevalent in the region. NB is an official bilingual province, where French communities are considered as linguistic minorities. Men in NB have the lowest life expectancy in Canada (77.5 years) and only $53.5 \%$ of men aged more than 18 in NB see their health as very good or excellent. They are under users of health services, only $72.9 \%$ of men visited their family doctor in the last year. Moreover, public health in NB is an emerging sector with a major focus on non-communicable diseases and children and youth health. Although HIV/AIDS prevention is an issue for NB public health, development of a well-structured and integrated program for HIV/AIDS prevention is in its infancy.

Knowing all that, there is currently no consensus on how to build an evidence-based comprehensive and integrated approach to prevent HIV/AIDS infection in men, and especially for those living in rural and remote areas. This scoping review aims to set the stage for the proposition of an evidence-based preventive intervention for men through the identification of best practice programs for sexual health promotion and of effective channels for reaching such men.

\section{Method}

We conducted a scoping review that adheres to the guidelines in the Preferred Reporting Items for Systematic Reviews and MetaAnalysis (PRISMA) statements [12]. The English and French language literature indexed in EBSCO (Medline, CINHALPsycINFO, and PsycARTICLES), Embase and ISI Web of Science from January 01, 2000 to December 31, 2012 was systematically searched in March 2013 using the following key words: (men OR Teenager OR adolescent OR boy) and (health* OR social OR community OR clinic ${ }^{\star}$ OR care) and (services OR setting OR program OR intervention OR approach) (see Figure 1). In addition, a manual search was conducted in five periodicals specialized in men's health (Men's Health Journal, Men and Masculinities, International Journal of Men's Health, American Journal of Men's Health and Psychology of Men and Masculinity) using the same time frame as the computerized database search (see Figure 1). Inclusion criteria for this selection of articles comprised empirical articles using either a qualitative or quantitative approach, publication domain in men's or male adolescent (15 or older) health and English or French language literature. Exclusion criteria included essays, book reviews, theses, editorials, project reports and grey literature. References were managed using Ref Works 2.0. A further, complementary review was made on computer-based and telephonebased interventions to derive practical recommendations (see Figure 1). The references of the selected studies were systematically checked to identify relevant articles that were not identified through the electronic and hand search strategies. From this pool of articles, three reviewers independently extracted information on: health topic (i.e. HIV/AIDS), design of services (structure and resources), modes of delivery, content of intervention and main outcomes for men.

\section{Findings}

\section{Descriptive statistics}

Studies that met inclusion and exclusion criteria and were evaluating the efficacy of an HIV/AIDS prevention intervention for men or male adolescents were selected. A total of 50articles were included from an initial total of 301 articles on sexual health (see Figure 1). An overview of these articles and descriptive data of the selected studies are presented in Table 1. Among the 50 articles, 36 studies were based on quantitative design and 10 on mixed method (qualitative and quantitative design). Among the 50 selected articles, 12 studies were based on a Randomized Clinical Trial (RCTs). The overall quality score of the 12 RCTs study design was assessed based on CONSORT Checklist criteria [13]. The quality score of the RCTs study design varied from good to somewhat good. All the studies had relevant theoretical foundation and used one of the following behavioral theories: the Behavioral Skills Acquisition Model, The Transtheoretical Model of Behaviour Change, The Decisional Balance Model, the Social Cognitive Theory and the Social Action Model. Only one study, led in South Africa, was based on the Social Constructionist Theory of Gender. From the 50 selected articles, 44 were exclusively targeting HIV/AIDS and 6 targeted HIV/AIDS and other health topics (hepatitis, Sexually Transmitted Diseases (STD), violence, drug use, alcohol, sexual behavior, sexuality, and mental health). In terms of geographic localization, based on country of intervention delivery and not on $1^{\text {st }}$ author affiliation, the distribution

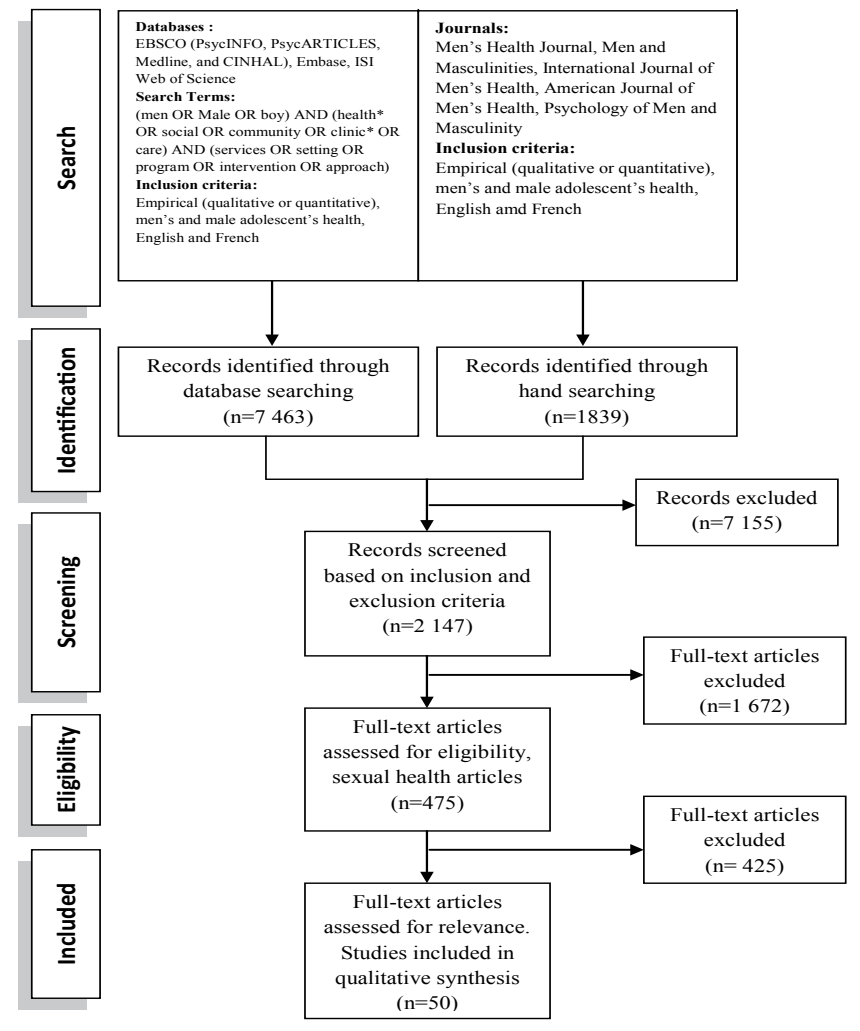

Figure 1: Flow chart of literature search results for effectiveness of HIVIAIDS prevention interventions for men's and male adolescents. 
Citation: Jbilou J, Robertson SS, Jazebizadeh H, Gallant L, Robinson M, et al. (2013) Men-centered Approaches for Primary and Secondary Prevention of HIVIAIDS: A Scoping Review of Effective Interventions. J AIDS Clin Res 4: 257. doi: 10.4172/2155-6113.1000257

Page 3 of 14

\begin{tabular}{|c|c|c|c|c|c|}
\hline Reference & $\begin{array}{l}\text { Geographic } \\
\text { localization }\end{array}$ & Population & Program description & Design & $\begin{array}{l}\text { Follow-up } \\
\text { observation }\end{array}$ \\
\hline $\begin{array}{l}\text { Aggarwal and } \\
\text { Duggal [31] }\end{array}$ & $\begin{array}{l}\text { Rural area } \\
\text { of Lalpur, } \\
\text { Ferozepur, } \\
\text { Andheri; } \\
\text { Haryana state; } \\
\text { North India }\end{array}$ & $\begin{array}{l}403 \text { males and } 329 \\
\text { females }\end{array}$ & $\begin{array}{l}\text { Type and model: Community-based, educational and advice (group and } \\
\text { individual) Content: } \\
\text { - Health education activities consisting of } 6 \text { RTI/STD camps ( } 2 \text { in each village) } \\
\text { including vaginal examination and free medication, and one-on-one counseling } \\
\text { and } 20 \text { interactive health education sessions (talks) ( } 2 \text { year duration). } \\
\text { - Use of health pamphlets (RTI and HIVIAIDS) in simple vernacular language. }\end{array}$ & QT & $\begin{array}{c}1 \text { month and } \\
2 \text { years }\end{array}$ \\
\hline Barss et al. [44] & $\begin{array}{l}\text { Al Ain and } \\
\text { Abu Dhabi in } \\
\text { Abu Dhabi } \\
\text { Emirate, } \\
\text { United Arab } \\
\text { Emirates }\end{array}$ & $\begin{array}{l}1398 \text { females and } 505 \\
\text { males (grade } 12 \text { high } \\
\text { school students) }\end{array}$ & $\begin{array}{l}\text { Type and model: School-based, educational (group) } \\
\text { Content: } \\
\text { - Peer-led school presentations about HIVIAIDS ( } 30-35 \text { minutes, brief history of } \\
\text { AIDS, prevalence, description of the disease, modes of transmission, treatment } \\
\text { and prevention) and } 3 \text { short workshops on attitude and stigma ( } 10 \text { minutes). }\end{array}$ & QT & $\begin{array}{l}\text { Post- } \\
\text { intervention }\end{array}$ \\
\hline Bing et al. [50] & Angola & 568 Male soldiers & $\begin{array}{l}\text { Type and model: Work-based, educational (group) } \\
\text { Content: } \\
-5 \text { day military focused interactive HIV prevention interventions including } \\
\text { monthly booster sessions available after each intervention. } \\
\text { - Based on Fisher and Fisher's Information, Motivation and Behavioral Skills } \\
\text { (IMB) model of behavior change. }\end{array}$ & QT & $\begin{array}{l}3 \text { and } 6 \\
\text { months }\end{array}$ \\
\hline Blas et al. [54] & Lima, Peru & $\begin{array}{l}808 \text { gay and } 588 \text { non- } \\
\text { gay MSM }\end{array}$ & $\begin{array}{l}\text { Type and model: Electronic-based, educational (individual) Content: } \\
-5 \text { minutes HIV-testing motivational videos framed within the Health Belief } \\
\text { Model and customized for three audiences ( } 1 \text {-non gay, s- } 2 \text { gay, s- } 3 \text { trans) } \\
\text { - Offered through } 7 \text { gay websites which included a link to online survey, } \\
\text { information about risk and benefits of participation, privacy policy information, } \\
\text { frequently asked questions and a phone number for more information. }\end{array}$ & QT - RCT & $\begin{array}{c}\text { mean of } \\
125.5 \text { days }\end{array}$ \\
\hline Bogart et al. [64] & $\begin{array}{l}\text { Los Angeles } \\
\text { County, } \\
\text { California, }\end{array}$ & $\begin{array}{l}121 \text { HIV-positive } \\
\text { clients, } 87 \% \text { male }\end{array}$ & $\begin{array}{l}\text { Type and model: non-randomized evaluation, in multivariate models } \\
\text { Content: } \\
\text {-a non-randomized evaluation examining relationships of TA (treatment } \\
\text { advocacy) participation to adherence, care engagement, social services } \\
\text { utilization, unmet needs, patient self-advocacy, and adherence self-efficacy } \\
\text { among } 121 \mathrm{HIV-positive} \mathrm{clients} \mathrm{(} 36 \text { in TA, } 85 \text { not in TA; } 87 \% \text { male) } \\
\text {-Participants completed 1-hour interviews at baseline, and at 3-and 6-month } \\
\text { follow-up. } \\
\text {-TA participants (vs. non-TA participants) showed higher electronically } \\
\text { monitored and self-reported adherence }\end{array}$ & QL, QT & $\begin{array}{l}\text { 3- and } \\
\text { 6-month } \\
\text { follow-up }\end{array}$ \\
\hline Bowen et al. [55] & $\begin{array}{l}\text { Wyoming and } \\
\text { Texas, USA }\end{array}$ & 90 MSM & $\begin{array}{l}\text { Type and Model: Electronic-Based, educational and advice (individual) } \\
\text { Content: } \\
- \text { Internet-delivered HIV risk-reduction intervention modules (conversation with } \\
\text { HIV + and - men, interactive graphics and activities) } \\
-2 \text { modules of } 20 \text { minutes (HIV testing, living with HIV, treatment issues and } \\
\text { routes of infection, safer sex options, condom types and correct condom } \\
\text { application) }\end{array}$ & QT - RCT & 1 week \\
\hline Boyer et al. [49] & $\begin{array}{l}\text { Western } \\
\text { pacific aboard } \\
\text { ships }\end{array}$ & $\begin{array}{l}584 \text { young US marine } \\
\text { males }\end{array}$ & $\begin{array}{l}\text { Type and model: Work-based, educational (group) } \\
\text { Content: } \\
\text { - Four 2-hours multicomponent interactive sessions facilitated by trained } \\
\text { navy corpsmen and a 2-hour booster session. (information, motivation and } \\
\text { behavioral skills models) }\end{array}$ & QT & 6 months \\
\hline Butler et al. [26] & 22 USA states & $\begin{array}{l}167 \mathrm{HIV}+\text { ado and } \\
\text { youth males with } \\
\text { haemo-philia }\end{array}$ & $\begin{array}{l}\text { Type and model: Community-based, educational and advice (individual and } \\
\text { group) } \\
\text { Content: } \\
\text { - Based on the Transtheoretical Model of Behavior Change and the Theory } \\
\text { of Reasoned Action. Intervention } 1 \text { (establish initial rapport and elicit input for } \\
\text { future programming -individual), intervention } 2 \text { (social activity with a group } \\
\text { session to develop a supportive peer group), intervention } 3 \text { (intensive weekend } \\
\text { retreat and recreational activities with group sessions) and intervention } 4 \\
\text { (facilitate continuing progress and relapse prevention- individual). }\end{array}$ & QT/QL & $\begin{array}{l}\text { Post- } \\
\text { intervention } \\
\text { and } 6 \\
\text { months }\end{array}$ \\
\hline Caron et al. [45] & $\begin{array}{l}\text { Quebec, } \\
\text { Canada }\end{array}$ & $\begin{array}{l}698 \text { junior and } 306 \\
\text { senior high school } \\
\text { students }\end{array}$ & $\begin{array}{l}\text { Type and model: School-based, educational (group) } \\
\text { Content: } \\
\text { - Protection Express Program (Peer-led) based on the Theories of Planned } \\
\text { Behavior and Interpersonal Behavior and a teaching model based on Social } \\
\text { Cognitive Theory. Content developed to affect attitude, perceived social norm, } \\
\text { perceived behavioral control, personal normative belief, role belief and the } \\
\text { belief underlying these main construct. }\end{array}$ & QT & $\begin{array}{c}2 \text { weeks } \\
(\mathrm{T} 1) \text {, and } 9 \\
\text { Months (T2) }\end{array}$ \\
\hline
\end{tabular}


Citation: Jbilou J, Robertson SS, Jazebizadeh H, Gallant L, Robinson M, et al. (2013) Men-centered Approaches for Primary and Secondary Prevention of HIVIAIDS: A Scoping Review of Effective Interventions. J AIDS Clin Res 4: 257. doi: 10.4172/2155-6113.1000257

Page 4 of 14

\begin{tabular}{|c|c|c|c|c|c|}
\hline $\begin{array}{l}\text { Chernoff and } \\
\text { Davison [43] }\end{array}$ & $\begin{array}{l}\text { California, } \\
\text { USA }\end{array}$ & 155 college students & $\begin{array}{l}\text { Type and model: College-based, educational and advice (group) } \\
\text { Content: } \\
-20 \text { minutes self administered intervention using normative feedback about } \\
\text { the prevalence of sexual risk behaviors among college students. Selection of } \\
\text { specific risk reduction goals by students to be implemented over a } 30 \text { day } \\
\text { follow up period. }\end{array}$ & QT & 30 days \\
\hline $\begin{array}{l}\text { Chesney et al. } \\
{[42]}\end{array}$ & $\begin{array}{l}\text { San Francisco } \\
\text { Bay Area, } \\
\text { USA }\end{array}$ & $\begin{array}{l}149 \text { gay men or } \\
\text { bisexual males (MSM) }\end{array}$ & $\begin{array}{l}\text { Type and model: Clinical-based, educational and advice (group) } \\
\text { Content: } \\
-10 \text { weekly training sessions in appraisal of stressful situations, problem } \\
\text { focused and emotional focused coping, fit between stressful situations } \\
\text { and coping strategies, and the use of social support; skill-building group } \\
\text { activities (relaxation guidance, day-long retreat, take home exercises) and } 6 \\
\text { maintenance sessions. }\end{array}$ & QT - RCT & $\begin{array}{l}3,6 \text {, and } 12 \\
\text { months }\end{array}$ \\
\hline $\begin{array}{l}\text { Coleman et al. } \\
{[14]}\end{array}$ & $\begin{array}{l}\text { Philadelphia, } \\
\text { USA }\end{array}$ & $\begin{array}{l}60 \text { older HIV }+ \text { African } \\
\text { American males }\end{array}$ & $\begin{array}{l}\text { Type and model: Community-based, educational (group and individual) } \\
\text { Content: } \\
-4 \text { week }(2 \mathrm{~h} / \mathrm{w}) \text { intervention to increase condom use (condom use activities; } \\
\text { information on stigma, marginalization, side effect of drug therapy and } \\
\text { comorbidities; the checking video; SWAT negotiation; take home assignment } \\
\text { with DVD). }\end{array}$ & QT & $\begin{array}{l}\text { Post- } \\
\text { intervention } \\
\text { and } 3 \\
\text { months }\end{array}$ \\
\hline Dilley et al. [38] & $\begin{array}{l}\text { San } \\
\text { Francisco, } \\
\text { USA }\end{array}$ & 248 gay males (MSM) & $\begin{array}{l}\text { Type and model: Clinical-based; advice (individual) } \\
\text { Content: } \\
\text { - One face to face counseling session focusing on self-justification (1 hour) - } \\
\text { introduction, recent history, critical examination and closure. }\end{array}$ & QT -RCT & $\begin{array}{l}6 \text { and } 12 \\
\text { months }\end{array}$ \\
\hline Exner et al. [39] & $\begin{array}{l}\text { Ibadan, } \\
\text { Nigeria }\end{array}$ & 281 males & $\begin{array}{l}\text { Type and model: Clinical-based, educational and advice (group) } \\
\text { Content: } \\
\text { - Two } 5 \text { hour workshops, with a monthly } 2 \text { hour check-in session (didactic } \\
\text { and interactive teaching, small group discussion, etc.). Modules: HIV stigma, } \\
\text { knowledge, prevention, risk reduction strategies, sexual negotiation and } \\
\text { gender based violence. Sessions: emphasis on communication, assertiveness } \\
\text { and negotiation skills. }\end{array}$ & QT & 3 months \\
\hline Harding et al. [9] & London, UK & 50 gay males & $\begin{array}{l}\text { Type and model: Community based, educational (group) } \\
\text { Content: } \\
\text { - «SMsex: an introduction to the sm scene»: } 25 \text { group members meet for four } \\
\text { sessions of } 7 \text { hours (assumption and knowledge, practical tools, risk taking, } \\
\text { fantasy, limits and boundaries). }\end{array}$ & QT - RCT & $\begin{array}{l}8 \text { and } 20 \\
\text { weeks }\end{array}$ \\
\hline Hoff et al. [24] & $\begin{array}{l}\text { New-York } \\
\text { City and San } \\
\text { Francisco, } \\
\text { USA }\end{array}$ & $\begin{array}{l}811 \text { HIV+ gay and } \\
\text { bisexual males }\end{array}$ & $\begin{array}{l}\text { Type and model: Community-based, educational and advice (group) } \\
\text { Content: } \\
\text { - The Seropositive Urban Men's Intervention Trial (SUMIT): behavioral } \\
\text { intervention including six peer led sessions ( } 3 \mathrm{~h} \text { ). (sexual and romantic } \\
\text { relationships, HIV and STD transmission, drug and alcohol use, assumptions } \\
\text { about HIV status of partners, HIV transmission responsibility and disclosure } \\
\text { of HIV status) }\end{array}$ & QT - RCT & $\begin{array}{l}3 \text { and } 6 \\
\text { months }\end{array}$ \\
\hline Jones et al. [15] & $\begin{array}{l}\text { Raleigh, } \\
\text { Greensboro } \\
\text { and Charlotte, } \\
\text { North } \\
\text { Carolina; USA }\end{array}$ & 1190 black MSM & $\begin{array}{l}\text { Type and model: Community-based, educational (group) } \\
\text { Content: } \\
\text { - HIV behavioral intervention of } 4 \text { two hour sessions on topics like: local and } \\
\text { state epidemiology of HIVIAIDS and STDs, facts and myths about HIVIAIDS } \\
\text { and characteristic of an effective risk reduction conversation. }\end{array}$ & QT & $\begin{array}{c}4,8 \text { and } 12 \\
\text { months }\end{array}$ \\
\hline $\begin{array}{l}\text { Kalichman et al. } \\
{[28]}\end{array}$ & $\begin{array}{l}\text { Eastern and } \\
\text { western cape } \\
\text { region of } \\
\text { South Africa }\end{array}$ & 99 Males & $\begin{array}{l}\text { Type and model: Community-based, educational and advice (group) } \\
\text { Content: } \\
\text { - Based on the Social Cognitive Theory and the Social Constructionist Theory } \\
\text { of Gender (five } 3 \mathrm{~h} \text { group sessions with } 8-12 \text { men). Includes elements of } \\
\text { education, motivational enhancement to reduce HIV risk and sexual violence, } \\
\text { HIVIAIDS destigmatization, and learning skills for avoiding violence and } \\
\text { reducing sexual risks. }\end{array}$ & QT & $\begin{array}{l}\text { After 5th } \\
\text { session }\end{array}$ \\
\hline Kegeles et al. [32] & $\begin{array}{l}\text { All regions of } \\
\text { the US; } 31 \\
\text { states, plus } \\
\text { the District of } \\
\text { Columbia and } \\
\text { Puerto Rico }\end{array}$ & $\begin{array}{l}49 \text { community- } \\
\text { based organizations; } \\
\text { population size: } \\
30,000-11,000,000\end{array}$ & $\begin{array}{l}\text { Type and model: Community-based, Translating Research into Practice } \\
\text { (TRIP) Study (a longitudinal project) } \\
\text { Content: } \\
\text {-Development of an intervention to help CBOs (community-based } \\
\text { organizations) implement the MP (Mpowerment Project: a community-level, } \\
\text { evidence-based HIV prevention intervention for young gay/bisexual men that } \\
\text { is a combination HIV prevention approach) called the Mpowerment Project } \\
\text { Technology Exchange System (MPTES). } \\
\text {-The MPTES consists of seven components (program manual, overview video, } \\
\text { M-group Facilitator Guide, M-group training video, Training program, Technical } \\
\text { assistance (TA) program, Web-based resources) }\end{array}$ & QL & $\begin{array}{l}\text { Up to } 2 \\
\text { years }\end{array}$ \\
\hline
\end{tabular}


Citation: Jbilou J, Robertson SS, Jazebizadeh H, Gallant L, Robinson M, et al. (2013) Men-centered Approaches for Primary and Secondary Prevention of HIVIAIDS: A Scoping Review of Effective Interventions. J AIDS Clin Res 4: 257. doi: 10.4172/2155-6113.1000257

Page 5 of 14

\begin{tabular}{|c|c|c|c|c|c|}
\hline Koblin et al. [8] & $\begin{array}{l}\text { Boston, } \\
\text { Chicago, } \\
\text { Denver, New } \\
\text { York, San } \\
\text { Francisco, } \\
\text { and Seattle; } \\
\text { USA }\end{array}$ & 4295 MSM & $\begin{array}{l}\text { Type and model: Community-based, educational and advice (individual) } \\
\text { Content: } \\
\text {-Intervention designed to address individual, interpersonal and situational } \\
\text { related factors associated with risk taking among MSM. Ten core modules } \\
\text { delivered at one-on-one counseling sessions (one module per session) within } \\
4-6 \text { months randomization. Maintenance sessions every } 3 \text { months until the end } \\
\text { of the study. }\end{array}$ & QT - RCT & $\begin{array}{l}\text { Every } 6 \\
\text { months }(4 \\
\text { years) }\end{array}$ \\
\hline Kubicek et al. [34] & $\begin{array}{l}\text { Los Angeles, } \\
\text { CA, USA }\end{array}$ & $\begin{array}{l}526 \text { YMSM (young } \\
\text { MSM; ages 18-24) }\end{array}$ & $\begin{array}{l}\text { Type and model: Community-based, longitudinal study of an ethnically } \\
\text { diversecohort } \\
\text { Content: } \\
\text {-Study about how YMSM use the Internet to find information related to } \\
\text { sex, sexuality, and sexual partners. HYM (Healthy Young Men) participants } \\
\text { completed an extensive } 60 \text { to } 90 \text { min survey every } 6 \text { months over the course } \\
\text { of } 2 \text { years. } \\
\text {-Findings show how YMSM researchers and interventionists can most } \\
\text { effectively reach YMSM through online methods. }\end{array}$ & QT and QL & $\begin{array}{l}\text { Every six } \\
\text { months over } \\
\text { the course of } \\
\text { two years }\end{array}$ \\
\hline Landolt et al. [65] & Thailand & $\begin{array}{l}100 \text { HIV-positive } \\
\text { women and } 100 \text { HIV- } \\
\text { positive men }\end{array}$ & $\begin{array}{l}\text { Type and model: Cross-sectional study; participants completed a questionnaire } \\
\text { Content: } \\
\text {-Study about the sexual life of HIV-positive heterosexual men and women in a } \\
\text { stable relationship and on successful antiretroviral therapy (ART) in Thailand. } \\
\text {-Sexual practices and options for contraception, as well as intention for } \\
\text { conception and factors influencing it were studied. }\end{array}$ & QT & N/A (None) \\
\hline Lapinski et al. [21] & $\begin{array}{l}\text { Michigan, } \\
\text { USA }\end{array}$ & 72 HIV+ MSM & $\begin{array}{l}\text { Type and model: Community-based, educational and advice (group and } \\
\text { individual) } \\
\text { Content: } \\
\text {-Individual level counseling condition (ILC): based on the Stage of Change } \\
\text { Model and the AIDS Risk Reduction Model, counselors assed HIV risk and } \\
\text { developed risks reduction plans; Group level sessions condition (GLS): } 6 \\
\text { peer facilitated group level sessions based on the Theory of Reasoned Action } \\
\text { and the Social Cognitive Theory and GLS and ILC arm condition: added } \\
\text { appropriated medical and psychosocial referrals. }\end{array}$ & QT & $\begin{array}{l}\text { Post- } \\
\text { intervention } \\
\text { and } 6 \text { weeks }\end{array}$ \\
\hline Leonard et al. [51] & $\begin{array}{l}\text { Kaolack, } \\
\text { Senegal }\end{array}$ & 260 males & $\begin{array}{l}\text { Type and model: Work-based; educational and advice (group) } \\
\text { Content: } \\
\text { - Peer education program (information on HIV and STD, condom distribution, } \\
\text { referrals, etc). }\end{array}$ & QT & 3 months \\
\hline $\begin{array}{l}\text { Mansergh et al. } \\
\text { [22] }\end{array}$ & $\begin{array}{l}\text { Chicago, Los } \\
\text { Angeles, New } \\
\text { York, San } \\
\text { Francisco; } \\
\text { USA }\end{array}$ & $\begin{array}{l}1686 \text { substance using } \\
\text { MSM }\end{array}$ & $\begin{array}{l}\text { Type and model: Community-based, educational and advice (group) } \\
\text { Content: } \\
-6 \text { weekly } 2 \text { hour group sessions consisting of an intervention (cognitive } \\
\text { behavioral techniques and skill building techniques including modeling and } \\
\text { behavioral rehearsal) and twelve } 45-55 \text { min modules of the attention-control } \\
\text { ( } 20-30 \text { min video and group discussion on MSM related issues such as } \\
\text { relationships, spirituality and racism). }\end{array}$ & QT - RCT & $\begin{array}{c}3,6 \text { and } 12 \\
\text { months }\end{array}$ \\
\hline Morin et al. [23] & USA & 616 MSM HIV+ & $\begin{array}{l}\text { Type and model: Community-based, educational and advice (individual) } \\
\text { Content: } \\
\text { - Cognitive behavioral intervention, individually tailored sessions, } 90 \text { minutes } \\
\text { individual counseling sessions grouped into } 3 \text { modules (stress coping and } \\
\text { adjustment/safer behavior/healthy behavior) each consisting of } 5 \text { sessions. }\end{array}$ & QT & $\begin{array}{l}5,10,15 \\
20 \text { and } 25 \\
\text { months }\end{array}$ \\
\hline $\begin{array}{l}\text { Mustanski et al. } \\
\text { [35] }\end{array}$ & $\begin{array}{l}\text { USA (Midwest } \\
\text { states) }\end{array}$ & $\begin{array}{l}329 \text { MSM } \\
\text { (18- to } 24 \text {-year-old) }\end{array}$ & $\begin{array}{l}\text { Type and model: Community-based mixed-methods; interviews, quantitative } \\
\text { and qualitative analysis } \\
\text { Content: } \\
\text {-Describing Internet-related behaviors among young MSM that positively } \\
\text { and negatively impact their sexual health. Three areas of sexual health } \\
\text { were explored: HIVISTI knowledge, sexual self-acceptance, and sexual risk } \\
\text { behaviors. } \\
\text {-Use of the Internet to find HIVIAIDS information was very common. } \\
\text {-The findings present an optimistic picture about the role of the Internet in the } \\
\text { development of sexual health among young MSM. }\end{array}$ & QT, QL & $\mathrm{N} / \mathrm{A}$ \\
\hline Ngongo et al. [66] & $\begin{array}{l}\text { Eastern and } \\
\text { Southern } \\
\text { Africa (Kenya, } \\
\text { Rwanda, } \\
\text { Uganda, } \\
\text { Zambia, and } \\
\text { South Africa) }\end{array}$ & $\begin{array}{l}16 \text { key staff members } \\
\text { from the } 10 \mathrm{RCs} \\
\text { (Research Centers) }\end{array}$ & $\begin{array}{l}\text { Type and model: data collection by a designed survey tool } \\
\text { Content: } \\
\text {-To inform a standard approach to care and prevention services in its sponsored } \\
\text { research, the International AIDS Vaccine Initiative (IAVI) conducted a survey to } \\
\text { systematically assess and document current practices at } 10 \text { HIV prevention } \\
\text { research centers (RCs) in Eastern and Southern Africa. } \\
\text {-A collaborative process between IAVI and the RCs was undertaken to reach } \\
\text { consensus on expected standards of care. A set of required and recommended } \\
\text { services to be provided on-site or by referral was developed. }\end{array}$ & QT, QL & $\mathrm{N} / \mathrm{A}$ \\
\hline
\end{tabular}


Citation: Jbilou J, Robertson SS, Jazebizadeh H, Gallant L, Robinson M, et al. (2013) Men-centered Approaches for Primary and Secondary Prevention of HIVIAIDS: A Scoping Review of Effective Interventions. J AIDS Clin Res 4: 257. doi: 10.4172/2155-6113.1000257

Page 6 of 14

\begin{tabular}{|c|c|c|c|c|c|}
\hline Njau et al. [36] & $\begin{array}{l}\text { Northern } \\
\text { Tanzania (in } \\
\text { rural settings) }\end{array}$ & $\begin{array}{l}91 \text { participants (male } \\
\text { and female) }\end{array}$ & $\begin{array}{l}\text { Type and model: Community-based, formative qualitative study, Purposive } \\
\text { sampling, interviews and Focus group discussions (FGDs) } \\
\text { Content: } \\
\text {-The Government of Tanzania has recognized a door-to-door recruitment } \\
\text { approach as a key strategy for universal HIV testing. Findings in this study } \\
\text { indicate that such an intervention is likely to be acceptable among couples and } \\
\text { service providers, although concerns remain that might limit uptake. }\end{array}$ & QL & $\mathrm{N} / \mathrm{A}$ \\
\hline $\begin{array}{l}\text { Operario et al. } \\
{[16]}\end{array}$ & $\begin{array}{l}\text { Oakland, CA, } \\
\text { USA }\end{array}$ & $\begin{array}{l}36 \text { African American } \\
\text { MSMW }\end{array}$ & $\begin{array}{l}\text { Type and model: Community-based, educational and advice (group) } \\
\text { Content: } \\
-4 \text { weekly } 1 \mathrm{~h} \text { counseling sessions (HIV prevention, interpersonal dynamics } \\
\text { with male and female partners and motivations of sexual episodes) } \\
\text { - Based on Information-Motivation-Behavioral Skills Model of HIV Behavior } \\
\text { Change and The AIDS Reduction model. }\end{array}$ & QT & 3 months \\
\hline Parsons et al. [30] & $\begin{array}{l}\text { Oklahoma, } \\
\text { USA }\end{array}$ & $\begin{array}{l}255 \text { HIV+ males with } \\
\text { haemophilia and } 158 \\
\text { females }\end{array}$ & $\begin{array}{l}\text { Type and model: Community-based, educational and advice (Individual and } \\
\text { group) } \\
\text { Content: } \\
\text { - } 3 \text { general communication skills modules, at least one stage based activity for } \\
\text { safer sex behaviors and at least one stage-based activity for communication } \\
\text { about safer sex behaviors. }\end{array}$ & QT & 15 months \\
\hline $\begin{array}{l}\text { Peacock et al. } \\
{[27]}\end{array}$ & $\begin{array}{l}\text { Johannes- } \\
\text { burg, South } \\
\text { Africa }\end{array}$ & 139 Males & $\begin{array}{l}\text { Type and model: Community-based, educational (group) } \\
\text { Content: } \\
\text { - Men as partner workshops intervention: educational workshops; } 4 \text { to } 5 \text { days ( } 35 \\
\text { hours of activities) on topics like gender and sexuality, violence, HIV prevention, } \\
\text { etc. }\end{array}$ & QT/QL & $\begin{array}{l}3 \text { to } 4 \\
\text { months }\end{array}$ \\
\hline Philips et al. [4] & $\begin{array}{l}\text { British } \\
\text { Columbia, } \\
\text { Canada }\end{array}$ & $\begin{array}{l}\text { N/A } \\
\text { (Commentary) }\end{array}$ & $\begin{array}{l}\text { Type and model: A commentary article that introduces a community-oriented } \\
\text { public health HIV prevention plan } \\
\text { Content: } \\
\text {-A group of experts criticize the current population-based public health } \\
\text { approaches for HIV prevention in North America. They propose a acommunity- } \\
\text { oriented public health approach for HIV prevention with a substantial attention } \\
\text { to sexual minorities (including MSM) as the at risk population. }\end{array}$ & QL & $\mathrm{N} / \mathrm{A}$ \\
\hline Picciano [57] & Seattle, USA & 89 MSM & $\begin{array}{l}\text { Type and model: Electronic-based, educational and advice (individual) } \\
\text { Content: - 90-120 min counseling session using a motivational interviewing } \\
\text { style. }\end{array}$ & QT - RCT & $\begin{array}{l}6 \text { and } 7 \\
\text { weeks }\end{array}$ \\
\hline Puccio et al. [58] & $\begin{array}{l}\text { Los Angeles, } \\
\text { USA }\end{array}$ & $8 \mathrm{HIV}+$ Young males & $\begin{array}{l}\text { Type and model: Electronic-based, cell phone reminders (individual) } \\
\text { Content: } \\
\text { - Cell phone reminders to improve HAART (highly active antiretroviral therapy) } \\
\text { adherence via a free cell phone. } \\
\text { - Participants received phone calls from an adolescent medicine research team } \\
\text { for } 12 \text { weeks (first } 4 \text { weeks calls occurred on a daily basis, weeks } 5 \text { through } \\
8 \text { calls were only made Monday through Friday, weeks } 9 \text { through } 12 \text { calls } \\
\text { occurred on Sunday, Tuesday, and Thursday). }\end{array}$ & QT/QL & $\begin{array}{l}4 \text { weeks } \\
\text { intervals } \\
\text { and post- } \\
\text { intervention } \\
\text { (24 weeks) }\end{array}$ \\
\hline Read et al. [56] & $\begin{array}{l}\text { Los Angeles, } \\
\text { USA }\end{array}$ & 110 MSM & $\begin{array}{l}\text { Type and model: Electronic based, educational and advice (individual) } \\
\text { Content: } \\
\text { - Counseling session: one-on-one AIDS counseling administered by a trained, } \\
\text { professional HIV counselor after a negative AIDS test. (review of safer sex } \\
\text { behavior, teaching behavioral and problem-solving skills for managing } \\
\text { cognitions and behavior when dealing with risky situations) } \\
\text { - Video: interactive virtual environment designed to simulate the emotional, } \\
\text { interpersonal, and contextual narrative of an actual sexual encounter while } \\
\text { challenging and changing MSM's more automatic patterns of risky responses } \\
\text { (peer-coach). }\end{array}$ & QT & $\begin{array}{l}\text { Post- } \\
\text { intervention }\end{array}$ \\
\hline $\begin{array}{l}\text { Rotheram-Borus } \\
\text { et al. [41] }\end{array}$ & $\begin{array}{l}\text { Los Angeles, } \\
\text { New } \\
\text { York, San } \\
\text { Francisco, } \\
\text { and Miami, } \\
\text { USA }\end{array}$ & $310 \mathrm{HIV}+$ youths & $\begin{array}{l}\text { Type and model: Clinical-based, educational and advice (group) } \\
\text { Content: Twenty three } 2 \mathrm{~h} \text { sessions based on The Social Action Model } \\
\text { - Stay Healthy intervention; a } 12 \text { session module that focuses on coping, } \\
\text { implementation of daily healthy routines, issues of disclosure and participating } \\
\text { in health care decisions. } \\
\text { - Act safe (11 sessions); enhance altruistic motivation to reduce transmission } \\
\text { acts. }\end{array}$ & QT & $\begin{array}{l}9 \text { and } 15 \\
\text { months }\end{array}$ \\
\hline
\end{tabular}


Citation: Jbilou J, Robertson SS, Jazebizadeh H, Gallant L, Robinson M, et al. (2013) Men-centered Approaches for Primary and Secondary Prevention of HIVIAIDS: A Scoping Review of Effective Interventions. J AIDS Clin Res 4: 257. doi: 10.4172/2155-6113.1000257

\begin{tabular}{|c|c|c|c|c|c|}
\hline Saberi et al. [37] & $\begin{array}{l}\text { California } \\
\text { (San } \\
\text { Francisco Bay } \\
\text { Area), USA }\end{array}$ & $\begin{array}{l}328 \text { men (MSM) (164 } \\
\text { couples) }\end{array}$ & $\begin{array}{l}\text { Type and model: a mixed-methods study, including qualitative sub-study } \\
\text { interviews } \\
\text { Content: } \\
\text {-They found that among } 328 \text { men, } 62 \% \text { had heard about PrEP (Pre-Exposure } \\
\text { Prophylaxis), but those at greatest risk may not be receptive of PrEP. Those } \\
\text { who engage in moderate risk express more interest in PrEP } \\
\text {-Results indicate a need for further education of MSM communities and the } \\
\text { need to determine appropriate populations in which PrEP can have the highest } \\
\text { impact. }\end{array}$ & QT, QL & \\
\hline Siegel et al. [46] & $\begin{array}{l}\text { Rochester, } \\
\text { NY; USA }\end{array}$ & $\begin{array}{l}4001 \text { middle and high } \\
\text { school students }\end{array}$ & $\begin{array}{l}\text { Type and model: School-based, educational (group) } \\
\text { Content: } \\
\text { - RAPP intervention is a } 10 \text { or } 12 \text { consecutive health class sessions ( } 2 \text { or } \\
3 \text { sessions per week) delivered for } 2 \text { to } 7 \text { weeks; based on the Theory of } \\
\text { Reasoned Action (in depth discussion and skills based activities). }\end{array}$ & QT & $\begin{array}{l}+-41.2 \\
\text { weeks }\end{array}$ \\
\hline $\begin{array}{l}\text { Sikkema et al. } \\
{[36]}\end{array}$ & $\begin{array}{l}\text { New York City, } \\
\text { USA }\end{array}$ & $\begin{array}{l}65 \text { men (newly HIV- } \\
\text { diagnosed MSM) }\end{array}$ & $\begin{array}{l}\text { Type and model: a collaborative, community-based approach; intervention } \\
\text { development and feasibility study (pilot intervention trial) } \\
\text { Content: } \\
\text {-The primary objective of this study was, in partnership with a large nonprofit } \\
\text { community health center, to develop, pilot test, and assess the potential } \\
\text { effectiveness of a theoretically based brief risk reduction intervention to reduce } \\
\text { HIV transmission risk among newly diagnosed MSM. } \\
\text {-The intervention comprised three } 60 \text {-minuteindividual sessions. } \\
\text {-Many individuals in the study reduced risk behavior immediately postdiagnosis. }\end{array}$ & QL & $\begin{array}{l}\text { 3-month, } \\
\text { and 6-month } \\
\text { follow-up }\end{array}$ \\
\hline $\begin{array}{l}\text { Somerville et al. } \\
{[18]}\end{array}$ & $\begin{array}{l}\text { California, } \\
\text { USA }\end{array}$ & $\begin{array}{l}766 \text { young Latino } \\
\text { migrants (MSM) }\end{array}$ & $\begin{array}{l}\text { Type and model: Community-based, educational (group) } \\
\text { Content: } \\
\text { - Modules on basic HIV information, communication, learning when to provide } \\
\text { information and when to provide referrals for professional assistance and STI. }\end{array}$ & QT & $\begin{array}{l}\text { Post- } \\
\text { intervention }\end{array}$ \\
\hline $\begin{array}{l}\text { Toro-Alfonso et } \\
\text { al. [19] }\end{array}$ & Puerto Rico & 587 Latino gay MSM & $\begin{array}{l}\text { Type and model: Community-based, educational (group) } \\
\text { Content: } \\
-15 \text { hours ( } 3 \text { hours small group discussion and four sessions workshops), } \\
\text { peer-led issues of intimacy, relationships, drug abuse, sexual behavior, HIV } \\
\text { and other STDs, and health perceptions. }\end{array}$ & QT & $\begin{array}{l}\text { Post- } \\
\text { intervention }\end{array}$ \\
\hline $\begin{array}{l}\text { Ugarte Guevara } \\
\text { et al. [33] }\end{array}$ & $\begin{array}{l}\text { León, } \\
\text { Nicaragua }\end{array}$ & 119 males (MSM) & $\begin{array}{l}\text { Type and model: mixed methods investigation, using a sequential triangulation } \\
\text { design in which qualitative in-depth interviews were followed by a quantitative } \\
\text { survey. } \\
\text { Content: } \\
\text { Fifteen participants (MSM) recruited by purposive sampling completed an } \\
\text { in-depth interview that was then thematically analyzed. An additional } 104 \\
\text { participants (MSM) were surveyed by means of an interviewer-administered } \\
\text { questionnaire. The study was conducted from September } 2008 \text { to May2009. } \\
\text {-Findings demonstrate a satisfactory understanding of HIV transmission } \\
\text { among MSM population. }\end{array}$ & $\begin{array}{c}\text { Mixed } \\
\text { (Intervews and } \\
\text { Questionnaires) }\end{array}$ & $\mathrm{N} / \mathrm{A}$ \\
\hline $\begin{array}{l}\text { Van der Borght et } \\
\text { al. [52] }\end{array}$ & $\begin{array}{l}\text { Congo, } \\
\text { Rwanda, } \\
\text { Brundi and } \\
\text { Nigeria }\end{array}$ & females and males & $\begin{array}{l}\text { Type and model: Work-based, educational and testing (individual and couple) } \\
\text { Content: } \\
\text { Comprehensive HIV workplace program (i.e. antiretroviral treatment, peer- } \\
\text { groups, special events, etc.) }\end{array}$ & QT & $\begin{array}{l}\text { Post- } \\
\text { intervention }\end{array}$ \\
\hline Walker et al. [47] & $\begin{array}{l}\text { Morelos, } \\
\text { Mexico }\end{array}$ & $\begin{array}{l}10954 \text { 1st year high } \\
\text { school students }\end{array}$ & $\begin{array}{l}\text { Type and model: School-based, educational (group) } \\
\text { Content: } \\
\text { - HIV education course with condom promotion condition }(15 \mathrm{w} / 30 \mathrm{~h}) \text { and the } \\
\text { same course plus emergency contraceptive and access condition (16 w/32 h) } \\
\text { (life skills teaching and UN program on HIV and AIDS). }\end{array}$ & QT -RCT & $\begin{array}{l}\text { Post- } \\
\text { intervention } \\
\text { and one } \\
\text { year }\end{array}$ \\
\hline Wiktor et al. [40] & $\begin{array}{l}\text { Abidjan, Côte } \\
\text { d'Ivoire }\end{array}$ & 559 males and females & $\begin{array}{l}\text { Type and model: Clinical-based; educational, advice and testing (individual } \\
\text { and group) } \\
\text { Content: } \\
\text { - HIV counseling sessions ( } 10-15 \text { minutes) - HIV transmission, knowledge and } \\
\text { prevention; misconceptions and reinforce correct responses. }\end{array}$ & QT & $\begin{array}{l}\text { Post- } \\
\text { intervention } \\
\text { and } 4 \\
\text { months }\end{array}$ \\
\hline Wilton et al. [17] & $\begin{array}{l}\text { New-York, } \\
\text { USA }\end{array}$ & 338 black MSM & $\begin{array}{l}\text { Type and model: Community based, educational and advice (group) } \\
\text { Content: } \\
-3 \mathrm{MV}: 5 \text { sessions intervention (behavioral and social determinants of HIV/STD } \\
\text { risks) based on the Social Cognitive Theory, The Behavioral Skills Acquisition } \\
\text { Model, The Transtheoretical Model of Behavior Change and The Decisional } \\
\text { Balance Model. }\end{array}$ & QT - RCT & $\begin{array}{l}3 \text { and } 6 \\
\text { months }\end{array}$ \\
\hline
\end{tabular}




\begin{tabular}{|c|c|c|c|c|c|}
\hline Wolitski et al. [25] & $\begin{array}{l}\text { California, } \\
\text { Mississippi, } \\
\text { Rhode } \\
\text { Island, and } \\
\text { Wisconsin; } \\
\text { USA }\end{array}$ & $\begin{array}{l}522 \text { young incarcerated } \\
\text { males }\end{array}$ & $\begin{array}{l}\text { Type and model: Community-based (prison), educational and advice } \\
\text { (individual) } \\
\text { Content: included prevention case management and motivational interviewing } \\
\text { and harm reduction } \\
\text { - Single session intervention: } 60-90 \text { minutes individual session based on a brief } \\
\text { HIV assessment and risk reduction planning intervention. } \\
\text { - Enhanced intervention: } 2 \text { schedule individual sessions before (60-90 minutes) } \\
\text { release and } 4 \text { after release (30-60 minutes). }\end{array}$ & QT & $\begin{array}{c}1,12 \text { and } 24 \\
\text { weeks }\end{array}$ \\
\hline Wolitski et al. [25] & $\begin{array}{l}\text { New-York } \\
\text { City and San } \\
\text { Francisco; } \\
\text { USA }\end{array}$ & $\begin{array}{l}811 \text { gay and bisexual } \\
\text { HIV+ males }\end{array}$ & $\begin{array}{l}\text { Type and model: Community-based, educational and advice (group) } \\
\text { Content: } \\
\text { - Six peer-led sessions }(3 \mathrm{~h}) \text { that addresses sexual and romantic relationships, } \\
\text { HIV transmission, drug and alcohol use, assumptions about HIV status of sex } \\
\text { partners, disclosure of HIV status and mental health. }\end{array}$ & QT - RCT & $\begin{array}{l}3 \text { and } 6 \\
\text { months }\end{array}$ \\
\hline Zhang et al. [20] & Anhui, China & 218 MSM & $\begin{array}{l}\text { Type and model: Community-based, educational and advice (group) } \\
\text { Content: } \\
\text { - Based on AIDS Risk Reduction Model ( } 4 / 1.5 \mathrm{~h} \text { sessions with activities), } \\
\text { sessions included: behavioral labeling and evaluating individual high risk } \\
\text { behaviors, developing individualized plans to make commitment to change } \\
\text { high risk behaviors, emphasized taking actions to change high risk behaviors. }\end{array}$ & QT & 3 months \\
\hline
\end{tabular}

QT: Studies using a quantitative design; QL: Studies using a qualtitative design; RCT: Randomized controlled trials; MSM: Men who have sex with men

Table 1: Preventive interventions overview and descriptive findings.

of articles was as follows: USA (30), South Africa (2), India (1), United Arab Emirates (1), Angola (1), Peru (1), Canada (2), UK (1), Nigeria (1), Tanzania (1), Senegal (1), Puerto Rico (1), Mexico (1), Côte d'Ivoire (1), China (1), Nicaragua (1), Thailand (1), and multi-African countries (Congo, Rwanda, Burundi, Zambia, Uganda, Kenya, South Africa, and Nigeria) (2). The studied interventions were targeting specific groups such as MSM, gay men, bisexual males and males living with HIV/ AIDS. Among the selected articles, 41were targeting only males and 9 had a female group for comparison. The interventions were of two categories: (1) general educational approaches providing information on HIV/AIDS, sexual health counselling, motivational interviews and behavioral skills development tools; and (2) Clinical preventive approaches combining health education and clinical examination or testing.

These interventions were delivered in different types of settings, 31 articles explored community-based interventions while 5 articles explored clinical-based, 5 explored school-based, 4 were work-based and 5 were provided through electronic channels (website or cellphone).

\section{Analytical synthesis of evidence}

Based on information extracted from the 50 selected articles, we identified some general trends that have implications for future research and practice. First, we identified a trend of evidence on the duration of effective interventions. HIV/AIDS face-to-face education sessions are more effective if their duration is less than 1 hour per session. Second, both individual and group based educational, counseling and psychosocial support strategies showed a positive impact on sexual risk behavior change strategies among men. Third, strategies targeting raising awareness and adopting screening behaviours (HIV testing among MSM) are shown to be effective. In the following, we will present the evidence synthesis in respect to intervention delivery setting: community-based, clinics-based, school-based, work-based and electronic-based interventions.

Community-based interventions: Among the 50 selected articles, 30 were exploring community-based interventions. These interventions were very heterogeneous in terms of type of prevention activities, targeted group and model of delivery. Indeed, 6 articles were conducted for specific MSM from ethnic and/or racial minority populations in the United States of America (USA). Four HIV prevention interventions for black and African American men led in USA were selected [1417]. Taken together, these interventions, which consisted of either counseling sessions and/or group educational sessions, were found effective in increasing condom use and decreasing risky sexual behaviors. Furthermore, two studies targeting Latino men $[18,19]$ were found effective in decreasing risky sexual behaviours through their educational interventions as was a peer-led educational and HIV testing study conducted in a Chinese setting [20]. In addition, four more prevention interventions studies were found effective in decreasing risky sexual behaviours through behavioural, cognitive, individual and/or group counseling sessions [8,21-23]. Communitybased interventions targeting gay men and bisexual men showed that peer-led behavioral educational interventions [24,25] are not particularly effective in decreasing unprotected sex among HIV positive gay and bisexual men. An RCT compared short (8 weeks) and mid-term (20 weeks) effectiveness of a multi-session group work for HIV prevention (4 group sessions, of 7 hours each), on safe sex in a context of sadomasochistic (SM) sex intercourse. This intervention is provided in a volunteer-led organization and aims to promote gay men's healththrough actions designed to meet the objectives of "Making It Count", a governmental program. This intervention was found effective in increasing knowledge, skills and attitudes [9]. However, this RCT has several limitations: the sample was exclusively white gay men, well-educated, it mixed men with different HIV status (HIV positive, HIV negative and HIV non-tested), and the age ranged from 24 to 70 years. A theory-based intervention, using the "Transtheoretical Model of Behavior Change" and the "Theory of Reasoned Action", for HIV positive young men and adolescents with haemophilia was found effective in increasing safer sex behaviors [26]. Two studies conducted in South Africa, which aimed to decrease domestic violence and HIV risk reduction through educational workshops [27] and a theorybased intervention [28], were found effective in increasing knowledge, attitudinal change, perception of stigma and/or risk reduction selfefficacy. One study explored an enhanced multisession intervention providing individual educational and advice sessions (including prevention case management and motivational interviewing and harm reduction) to MSM (18 to before and after prison release [29]. HIV 
prevention information was integrated with more general information on competing issues affecting MSM's ability to successfully re-enter the community after prison release. This large study revealed lower reported rates of unprotected sexual intercourse with main partners in the enhanced intervention group. Two studies explored the effectiveness of interventions for HIV positive men with hemophilia and their female partners [30,31]. Parson et al. [30] found significant differences with regards to safer sex behaviors, communication and condom selfefficacy after a mixed intervention (individual sessions and group sessions). Aggarwal and Duggal [31] tested a complex health-education intervention in a rural community. The intervention was based on health education activities consisting of 6 reproductive tract infections (RTI) or STD camps ( 2 in each village) including vaginal examination and free medication, one-on-one counseling, 20 interactive health education sessions (talks) and distribution of health pamphlets (RTI and HIV/AIDS) in simple vernacular language. The follow-up at 1 and 24 months after intervention showed no effective impact on increasing the average total knowledge score in men.

In a large study in the USA [32], the development of an intervention discussed; an intervention to help CBOs (communitybased organizations) implement the MP (Mpowerment Project, a community-level, evidence-based HIV prevention intervention for young gay/bisexual men that is a combination HIV prevention approach: small groups, community outreach, publicity, a drop-in center, and community mobilization). Mathematical modeling has demonstrated that MP is one of the intervention strategies with the potential to prevent the greatest number of new HIV infections in the US in a cost effective manner. The program has been implemented in over 150 US CBOs. They called this intervention Mpowerment Project Technology Exchange System (MPTES). The seven-component MPTES was provided to $49 \mathrm{CBOs}$ implementing the MP that were followed longitudinally for up to two years. They found that except for the widely used program manual, other program materials were used early in implementing the MP and then their use declined. In contrast, once technical assistance was proactively provided, its usage remained constant overtime, as did requests for technical assistance.

In a study in Nicaragua Ugarte Guevara et al. [33], findings demonstrate a satisfactory understanding of HIV transmission among MSM population, $75 \%$ of whom reported concerns of becoming infected with HIV in the future. Approximately one-half claimed that they always used condoms when having sex with men, but only onethird of the time with women, indicating inconsistent condom use.

Having an understanding of the risks associated with searching for partners online, and how and why YMSMuse the Internet for a variety of purposes, can inform the development of more effective Internet-based risk reduction programs. Kubicek et al. [34] in their study, showed that YMSM (young MSM) used the Internet to find information related to sex and sexuality; and how YMSM researchers and interventionists can identify how to most effectively reach YMSM through online methods.

Participants in a large study in the USA [35] reported that the Internet filled an important and unmet need for sexual health education. There was no evidence of increased risk behaviours with partners met online, but at the same time the potential for the use of the Internet to facilitate safer sex communication was largely untapped. Their findings generally present an optimistic picture about the role of the Internet in the development of sexual health among young MSM.

The results of these two studies regarding the Internet use by MSM and especially Young MSM can be used effectively in developing the prevention intervention for HIV/AIDS and promotion of sexual health plans in rural areas. In these areas, where people live in small communities that some times are far from major health promotion facilities, the on-line intervention and educational methods can reach lots of people particularly the young men. Both of these studies found that young MSM made extensive use of the Internet to find sexual health information.

In Tanzania approximately $6 \%$ of the adult population are infected with HIV, but fewer than $30 \%$ of adults reporting ever receiving an HIV test. In a formative study, Njau et al. [36] assessed the acceptability of a home-based couples counselling and testing (HBCCT) approach in rural settings in Northern Tanzania. HIV testing is considered as gateway to HIV prevention. An HBCCT intervention appears to be broadly acceptable among participants. Their findings are promising for interventionists in rural areas, although cultural differences should be considered in individual communities or countries.

In a study regarding PrEP (Pre-Exposure Prophylaxis) for HIV in MSM couples [37], Findings suggest that those at greatest risk may not be receptive of PrEP. Those who engage in moderate risk express more interest in PrEP; however, many voice concerns of increased risk behavior in tandem with PrEP use. Results indicate a need for further education of MSM communities and the need to determine appropriate populations in which PrEP can have the highest impact.

Philips et al. [4] in their commentary article, proposed development of a comprehensive HIV prevention program based on $\mathrm{COPH}$ (Community-Oriented Public Health). COPH is the discipline that applies population health principles in the context of the community'shealth. It deals with the identification and analysis of the health status and its determinants in a particular community, group of communities, or geographic region. It is followed by interventions addressing the community's health needs and their determinants through promotion, and prevention actions through multidisciplinary and intersectoral Cooperation.

Clinical-based prevention interventions: Clinical-based interventions are mainly provided in primary care clinical settings or public health clinics providing prevention services. Six clinicalbased prevention interventions were included in this scoping review. Interventions consisting of HIV counseling/testing and group educational sessions were found effective in decreasing risky sexual behaviors, decreasing stigmatized beliefs, increasing HIV testing and/ or increasing reported condom use in gay men, bisexual men and heterosexual men [38-40]. These studies were conducted in different countries involving a wide range of strategies. We also identified a complex prevention intervention for youth living with AIDS that was clinic-based and included numerous educational sessions targeting health in general and social responsibility [41]. This intervention was found ineffective in improving positive lifestyle changes and active coping styles in men. Finally, a coping effectiveness training intervention was found effective in decreasing perceived stress/burnout and increasing coping self-efficacy in HIV positive MSM [42].

In their article, Sikkema et al. [3] introduce a plan for secondary prevention of HIV infection in newly diagnosed MSM. From a behavioural perspective, the first year after receiving a diagnosis appears to be a critical period for risk reduction, particularly for men. Failure to take advantage of this "teachable moment" may be a missed opportunity to reduce HIV transmission risk at a critical 
period. Given the disproportionate burden of HIV among MSM, the benefits of early intervention for positive prevention, and the paucity of research in this area, there is an urgent need for the development and evaluation of HIV positive prevention interventions that can be delivered to newly diagnosed MSM in the HIV primary care setting. The primary objective of their study was, in partnership with a large non-profit community health center, to develop, pilot test, and assess the potential effectiveness of a theoretically-based brief risk reduction intervention to reduce HIV transmission risk among newly diagnosed MSM. They explored whether the intervention reduced sexual risk behaviour, substance use, traumatic stress related to being diagnosed with HIV, and increased uptake of services offered at the community health center. Consistent with the literature, many individuals in their study reduced risk behaviour immediately post diagnosis. However, continued transmission risk behaviour was evident among a subset of this high-risk sample. This is of particular public health significance as a large proportion of the sample was likely recently infected with HIV and a significant portion had a high viral load. Participants in the intervention condition, compared to the control condition group, reduced their number of sexual partners and use of alcohol [3]. Secondary prevention can be considered as an important part of the prevention intervention plans in rural areas.

School-based prevention interventions: School-based prevention interventions have the potential to reach large numbers of young boys before or during their first sexual experiences. Through educationalbased programs, the target population could acquire skills and tools for HIV/AIDS infection risk reduction and prevention. Frequently, schoolbased interventions aim at reinforcing empowerment and decisioncontrol. In this scoping review, we identified 5 school-based prevention interventions delivered in heterogeneous populations. A risk behavior prevention intervention for college students using normative feedback and goal setting was effective in increasing reported condom use in men [43]. The other studies retrieved showed mixed results. For instance, a peer-led workshop on HIV/AIDS knowledge and attitudes was found less effective in men than in women [44]. Educational sessions were found effective in increasing knowledge, self-efficacy, behavior intention and/or self-reported behaviors in young boys who were involved in less risk (e.g. not yet sexually active) at study enrollment $[45,46]$. However, these interventions showed less effectiveness on intention to practice safe-sex behaviors among young boys reporting previous sexual experience. Finally, a life skills teaching intervention, based on a combination of a local educational program and a UN program on HIV and AIDS, showed that young boys (in high school) reported using a condom with a sex worker or a casual partner more often than those in the control group although efficacy results were limited [47].

Work-based prevention interventions: Work-based prevention interventions have been shown to be an effective way to engage men in health promotion in the context of the working day, having the advantage of reaching people in their work environment without having to attend meetings or sessions after work hours [48].

Four work-based prevention interventions were selected in this review. Two military-setting interventions, involving men, found divergent results. A cognitive-behavioral skill-building interactive group session was found ineffective in influencing motivation or behavioral skills factors [49] while a 5 day military focused HIV prevention intervention was effective in reducing reported risky sexual behaviors and increasing HIV/AIDS knowledge [50]. Furthermore, a peer-mediated education and condom distribution program in male transport workers has been shown effective in altering AIDS related knowledge, attitude and behavior [51]. Finally, long-term, voluntary, individual or couple counseling and HIV testing was found to be less successful in reaching male employees than female employees [52].

Electronic-based prevention interventions: Electronic based prevention interventions can facilitate reach to large populations through the web or through other sources such as phones and mobile devices. These types of outreach media have the advantage of offering interventions in an anonymous way; important considering the high stigmatization around HIV/AIDS and the merits attached to privacy and confidentiality in health services for men [53]. Five electronic-based prevention interventions for MSM were selected in this review search. Computer-based individual online educational videos, interactive virtual environments and internet modules are effective in increasing HIV testing, knowledge and/or reported safer sex practices in men [5456]. Furthermore, individual cell phone reminders and telephone based brief counseling interventions using a motivation interviewing style are effective in improving knowledge, antiretroviral therapy adherence and/or reported safer sex practices in men $[57,58]$.

In two community-based studies that were mentioned earlier in this review $[34,35]$, though they didn't propose any prevention intervention plan for HIV/AIDS, their findings are promising about using electronic-based technologies to develop new intervention plans. They found that among MSM and especially young MSM Internet has an important role in finding sexual health information. They explored the role of the Internet in the sexual health of ethnically diverse young MSM. Quantitative results from a large survey of young MSM that tested HIV negative in a community clinic demonstrated high level of Internet use. The vast majority of the participants used the Internet a minimum of several times each week. Similarly, use of the Internet to find HIV/AIDS information was very common. A unique finding in their study was the sexual orientation differences in frequency of Internet use, with MSM using the Internet significantly more frequently (daily use $\mathrm{MSM}=77 \%$, non-MSM=60\%) [35]. Additionally, their data provide an opportunity to see how young MSM use a variety of different media within the Internet. Understanding what is attractive to young men (e.g., photos, insightful profiles) can be useful when considering web-based interventions [34].

\section{Discussion}

Unfortunately, both Canada and the United States have concentrated epidemics of HIV/AIDS. The sexual minorities (including MSM) continue to carrythe largest burden of HIV in both Canada and theUnited States [4]. According to the United Nations General Assembly, the political declaration on HIV/AIDS calls for each country to "define the specific populations that are key to its epidemic and response, based on the epidemiological and national context". Recognizing health care in equities and disparities among sexual minorities offers a glimmer of hope that the health needs of these communities will be addressed. The men and especially MSM is a distinct population group with its own specific health needs. Furthermore, the experiences of individuals are not uniform and are shaped by factors of race, ethnicity, socioeconomic status, geographical location, and age, any of which can have an effect on health-related concerns. Additionally, the identification of a need to improve medical and health sciences education related to community and sexual minority health across North America is promising for the development of HIV prevention interventions tailored to the needs of communities. Researchers still have a great deal to learn and face a number of challenges in understanding the health 
needs of sexual minority populations [4]. The practical application of $\mathrm{COPH}$ (Community-Oriented Public Health) in the developmentof a comprehensive approach to HIV prevention among sexual minority communities starts with strategic planning. Strategic planning entails the development of plans that include analysis of intervention alternatives and available resources to best address priority health issues in the community. The COPH function of adapting policies to the local level entails adapting national policies to the specific community's needs and the local scene and culture (i.e., context). These functions provide the basis for conducting a community health assessment. The community health assessment process begins with the identification of existing data sources and the initiation of studies to gather new information about the community's health status and its determinants, needs, and assets. This process includes the performance of health surveillance and an analysis of equitable service provision, gaps in services provided, and health inequalities. For instance, based on the available health surveillance data for British Columbia, the provincial response to HIV prevention should be tailored to the community needs of the priority populations of sexual minorities, injecting drug users (IDU), and Aboriginal people. In New Brunswick, we need up-to-date health surveillance data for making a strategic plan.

Each of the community health assessment findings must be addressed in the development, implementation, and evaluation of comprehensive COPH (Community-Oriented Public Health) HIV prevention interventions. In the development, implementation, and evaluation of a comprehensive COPH HIV prevention intervention, the governments should be encouraged to explore the use of a participatory contextual analysis. A participatory approach to the development of a comprehensive COPH HIV intervention engages communities in theprocess of problem solving, builds on local knowledge, and generates an indigenous response that is sustainable [4].

This scoping review aimed to identify effective HIV/AIDS prevention interventions tageting the male population. The extracted information has demonstrated mixed results. However, and importantly, the majority of interventions have been shown to be effective in improving knowledge, attitudes and behaviours.

For clinic based interventions, our scoping review showed that there is a paucity of knowledge on when, what and how HIV related information and counselling should be provided to target populations. Moreover, there is lack of evidence on who should provide this information, nurses or general practitioners.

Prevention with persons living with HIV/AIDS (PLWHA), commonly referred toas secondary or positive prevention, has become a central component of a multipronged approach to fighting the HIVepidemic. Withregard to MSM, studies indicate that over $50 \%$ of recently diagnosed MSM report sexual risk behavior within 3-12 months of diagnosis and while the majority respond to their HIV diagnosis by adopting lower risk sexual behaviors, a substantial proportion continue to engage in high risk sexual behaviors. Evidence suggests that positive prevention efforts should target people soon after HIV diagnosis. The newly diagnosed may include those with recent infection, and has been linked to nearly $50 \%$ of primary infections in some predominantlyMSM populations [3].

To improve school-based interventions, they have to be implemented earlier in adolescence, before the onset of risky behaviors. However, young people are reluctant to use sexual health services and may need to be reassured about privacy and confidentiality to have positive impact on safe sex-behavior [59]. Electronic or computer-based interventions offer an interesting avenue and "may serve as a complementary part of an overall behavioral and biomedical strategy for reducing sexual risk by addressing the specific needs and circumstances of the target population, and by changing individual knowledge, motivations, and community norms" [60].

Understanding what is attractive to MSM can certainly inform the development to of new and innovative web-based interventions, which are becoming increasingly important given their potential to reach a larger audience and have greater impact. More interactive web-based spaces should also be considered, such as chat rooms and virtual environments where MSM can learn from their own and others' ideas [34]. Individual online educational videos, interactive virtual environments and internet modules were effective in increasing HIV testing, knowledge and/or reported safer sex practices among MSM. Individual cell-phone reminder and telephone-based brief counseling interventions using a motivation interviewing style are also effective in improving knowledge, antiretroviral therapy adherence and/or reported safer sex practices in MSM. Work-based interventions are an adequate strategy to reach men. Evidence on effectiveness of strategies among military men is controversial. Moreover, some peer-led behavioural interventions showed low effectiveness among gay men. Finally, it is to be noted that interventions designed for men only, showed clear effectiveness compared to interventions targeting both men and women. Not surprisingly, this demonstrates that health interventions need to be gender-sensitive to men's needs as well as women's needs when developing and implementing health promotion options.

In summary, most interventions identified in this review have shown to be effective in improving knowledge, attitudes and sexual behaviors in men. None of the studies explored predictors of non-compliance to safe sex and HIV testing behavior among men in general. But, some of them have highlighted barriers and facilitators for achieving the goal of an HIV-free generation among sexual minority communities including MSM. They have been critical of the approach taken by the governments to respond to their concentrated HIV epidemics using a population-based public health approach that is targeted to the general population rather than specific communities that are most affected by HIV [4]. E-Health prevention interventions seem particularly effective among men. HIV studies follow a trend in terms of the elements that make for effective interventions: (1) target secondary prevention and (2) target specific populations such as MSM, gay males and HIV positive men. There is a clear need for evidence on effective strategies to improve HIV testing and to support safer sex among men of all sexual orientations. We need to rethink public health strategies and primary care, using a gender main stream analysis integrating context (rural/ urban), cultural and social context (hegemonic masculinity) and sexual orientation (gay/non gay), to help improve men's health and reduce gender iniquities. Moreover, sexual behavior and help seeking (i.e. utilization of healthcare services and social support) are negatively impacted by dominant heteronormative cultural ideals [61].

Lessons to be learnt, by New Brunswick, from international experiences for HIV prevention among men are in relation to: (1) Developing more men sensitive HIV prevention interventions; (2) Designing multi-faceted HIV prevention approaches targeting men; and (3) Integrating technology in public health interventions targeting men. However, before designing "one size fits all" interventions more research is needed to explore the social context of $\mathrm{NB}$ men to better understand the existing association between culture, beliefs, values, 
language, etc. and health care use behaviour in NB men. Moreover, there is a clear need for a better understanding for specific factors such organizational factors (i.e. access to healthcare services, men-sensitive public health programs, men-targeting health promotion and education intervention) and professional factors (i.e. men's health awareness, men-sensitive health communication skills).

This study aims to identify major trends in men-oriented HIV prevention interventions to help develop a structural basis for a comprehensive program for a rural Canadian context. However, this scoping review has some limitations. The first limitation relates to the diversity of included interventions. We have decided to include a wide range of interventions instead of focusing on only one type to explore all facets that might need to be included in a comprehensive strategy for HIV prevention among men. The last limitation is the heterogeneity of studies in terms of geographic location. Organizational, clinical and socioeconomic and cultural factors have a major impact on how to design, deliver and assess effectiveness of an intervention. However, reviewing studies from different countries can be considered as one of the strengths of this scoping review. It provides comprehensive information and a wide range of potential interventions that can be rethought and adjusted to particular contexts, such as rural and remote areas in Canada. Moreover, it adds to our knowledge about the major components of comprehensive and integrated plans to consider for NB. But, at the same time, differences in terms of organizational structure, economic condition, and cultural and social determinants have to be considered when it is time to develop and design an intervention model for New Brunswick. We call here for local NB studies to explore adequacy, appropriateness and relevance of the strategies identified in this study. More research will be needed to assess their feasibility, acceptance and effectiveness among NB men.

\section{Conclusion}

Canada has concentrated epidemics of HIV/AIDS. A concentrated epidemic is one in which the prevalence of HIV is firmly established in one or more subpopulations but not the entire population. Operationally, in a concentrated epidemic, HIV prevalence among specific subpopulations consistently exceeds $5 \%$ of that subpopulation but is below $1 \%$ among pregnant women in urban areas. The distinction between different kinds of HIV epidemics provide health officials and public-policy makers with data about the magnitude of the problem that HIV represents in their jurisdictions. This information can help health officials and public-policy makers to devise strategies for prevention of new HIV infections and can guide resource allocation to individuals and groups most in need. When epidemiologic evidence is available and used appropriately, the result is evidence-based health care. By design, population based public health interventions may not use community-based needs assessments and are based on aggregate data. Given these limitations, population-based public health reduces the likelihood of gaining sufficient information to target populations that are most at risk, are not sustainable public health approaches, and may not be the best or most efficient use of public health resources. This creates unique challenges for populations at risk for HIV, because public health resources are mobilized inequitably and target the entire population rather than individuals and groups most at risk for acquiring the disease. Sexual minorities, including MSM, continue to carry the largest burden of HIV in Canada. Using available epidemiological data and understanding the national and regional contexts in which the populations at risk live, HIV prevention interventions can be tailored to the needs of priority populations. This strategy will provide health care systems with the most efficient community-oriented HIV prevention interventions. Men, and especially MSM, are a distinct population group with their own specific health needs. For New Brunswick we propose the development of a comprehensive HIV prevention program based on community-oriented public health $(\mathrm{COPH}) . \mathrm{COPH}$ is the discipline that applies population health principles in the context of the community's health. It deals with the identification and analysis of the health status and its determinants in a particular community, group of communities, or geographic region. It is followed by interventions addressing the community's health needs and their determinants through promotion, and prevention actions through multidisciplinary and intersectoral cooperation. It is described by definition, as community-based and acting through different environmental "settings where people live, study, work, receive care, or spend their leisure time"; in short, the environmental context. $\mathrm{COPH}$ requires the application of specific functions to guide comprehensive HIV prevention program design, implementation, and evaluation. These functions include strategic planning; adapting policies to the local level; community health assessment; development, implementation, and evaluation of interventions; service-oriented research; capacity building; and coalition building. The practical application of $\mathrm{COPH}$ in the development of a comprehensive approach to HIV prevention among communities starts with strategic planning. Strategic planning entails the development of plans that include analysis of intervention alternatives and available resources to best address priority health issues in the community. These functions provide the basis for conducting a community health assessment. The community health assessment process begins with the identification of existing data sources and the initiation of studies to gather new information about the community's health status and its determinants, needs, and assets. This process includes the performance of health surveillance and an analysis of equitable service provision, gaps in services provided, and health inequalities. A participatory approach to the development of a comprehensive COPH HIV intervention engages communities in the process of problem solving, builds on local knowledge, and generates an in digenous response that is sustainable. The next function of $\mathrm{COPH}$, service-oriented research, provides the basis for health assessments, intervention program development, program evaluation, and continued HIV disease surveillance. Capacity and coalition building are the final functions of COPH. Effective capacity building not only includes work force preparation in the methods needed but also considers the indigenous knowledge and understandings of the health problem inherent in the affected community. Coalition building in the form of establishing partnerships among all community stake holders (e.g., members of the affected community, health services, other social services) facilitates the pooling of human and economic resources that contribute to the sustainability of $\mathrm{COPH}$ programs [4]. Health-care workers in the primary care clinics should have a good knowledge of HIV/AIDS and especially the most recent epidemiologic data in their communities. They should know about the high-risk population and their health needs. There is a good opportunity to discuss about sexual health including HIV/AIDS when people come for HIV testing. These clinics are an essential part in implementation of prevention interventions and particularly in the secondary prevention. They are also good places for researchers to collect epidemiologic data and study the different intervention plans. In New Brunswick, these clinics are not usually crowded and time for sexual health education could be scheduled.

There is a need to design RCTs protocols that exploremen's 
Citation: Jbilou J, Robertson SS, Jazebizadeh H, Gallant L, Robinson M, et al. (2013) Men-centered Approaches for Primary and Secondary Prevention of HIVIAIDS: A Scoping Review of Effective Interventions. J AIDS Clin Res 4: 257. doi: 10.4172/2155-6113.1000257

Page 13 of 14

responsiveness and compliance to HIV/AIDS prevention strategies and to launch a multidisciplinary Research Program to address demographic, geographic (rural versus urban), social, psychological, organizational and policy issues of men's sexual health services in New Brunswick. More research is needed to identify relevant and optimal effective strategies to be used by health professionals to raise HIV awareness. Such strategies have to be not only sexual orientation sensitive, but also culture, literacy and economic situation sensitive to adapt the message in terms of format, content and delivery mode.

There is also a need to develop research agendas to better clarify why and how men acquire, synthesize and embed sexual health information and transform it into healthy behaviors and to consider what determinants may influence (positively or negatively) this process. Furthermore, there is a need for more evidence on the efficacy of e-health or the so called mobile-Health (or m-Health) prevention interventions. Considering the expansion of the technologies and electronics resources available (i.e. smartphones, electronic tablets, etc.) and their popularity, such media could be used to increase effectiveness within prevention programmeswhich aim to reach men and particularly male adolescents.

Rethinking public health strategies and primary care, using gender based analysis which integrates context (rural/urban), sexual orientation (gay/non gay) and culture, may help improve men's health and reduce gender iniquities $[62,63]$. The design and development of gender sensitive public health programs as well as the implementation of equitable and ethically sound policies to improve men's sexual health are essential. In addition, fostering a better understanding of the political implications of men's sexual health in Canada and in New-Bruns wick may help public health authorities to develop more effective malefriendly services and programs. There is an urgent need for accurate evidence to develop evidence-based criteria and guidelines for clinical practices integrating male perspectives. These clinical strategies and tools have to target not only HIV but also other health issues. Building effective personalized preventive medicine practices for men will call for a better understanding of how men process health information and what factors may impact the shift from knowledge and attitude to behavior and lifestyle change and safe sex behavior maintenance.

\section{Funding}

This study was made possible through two (2) financial grants from Health Canada through the Consortium National de Formation en Santé-Secretariat national.

\section{References}

1. World Health Organization (2009) Data on the size of the epidemic, Number of adults, women and children living with HIV.

2. Public Health Agency of Canada (2012) HIV and AIDS in Canada: Surveillance Report to December 31st, 2011. Surveillance and Risk Assessment Division, Centre for Communicable Diseases and Infection Control, Public Health Agency of Canada.

3. Sikkema KJ, Hansen NB, Kochman A, Santos J, Watt MH, et al. (2011) The Development And Feasibility Of A Brief Risk Reduction Intervention For Newly HivDiagnosed Men Who Have Sex With Men. J Community Psychol 39: 717-732.

4. Phillips JC, Morrisseau-Beck DA, Patsdaughter CA (2012) "We don't think you're special": is equitable HIV prevention for sexual minorities possible? J Assoc Nurses AIDS Care 23: 478-486.

5. Centers for Disease Control and Prevention (2008) HIVIAIDS in the United States. Centers for Disease Control and Prevention, Atlanta, GA.

6. Public Health Agency of Canada (2010) Actualités en épidémiologie VIH/SIDA.
7. Xia Q, Nonoyama A, Molitor F, Webb D, Osmond D (2011) Recent decline in the incidence of human immunodeficiency virus infection among California men who have sex with men. Am J Epidemiol 174: 203-210.

8. Koflancet 364: 41-50.

9. Harding R, Bensley J, Corrigan N, Franks L, Stratman J, et al. (2004) Outcomes and lessons from a pilot RCT of a community-based HIV prevention multisession group intervention for gay men. AIDS Care 16: 581-585.

10. Bailey JV, Murray E, Rait G, Mercer CH, Morris RW, et al. (2012) Computerbased interventions for sexual health promotion: systematic review and metaanalyses. Int J STD AIDS 23: 408-413.

11. New-Brunswick Department of Health (2006) Declared cases of HIV and AIDS - 1985 to 2006.

12. Moher D, Liberati A, Tetzlaff J, Altman DG, PRISMA Group (2009) Preferred reporting items for systematic reviews and meta-analyses: The PRISMA statement. Ann Intern Med 151: 264-269.

13. CONSORT (2010) The CONSORT Statement.

14. Coleman CL, Jemmott L, Jemmott JB, Strumpf N, Ratcliffe S (2009) Development of an HIV risk reduction intervention for older seropositive African American men. AIDS Patient Care STDS 23: 647-655.

15. Jones KT, Gray P, Whiteside YO, Wang T, Bost D, et al. (2008) Evaluation of an HIV prevention intervention adapted for Black men who have sex with men. Am J Public Health 98: 1043-1050.

16. Operario D, Smith CD, Arnold E, Kegeles S (2010) The Bruthas Project: evaluation of a community-based HIV prevention intervention for African American men who have sex with men and women. AIDS Educ Prev 22: 37-48.

17. Wilton L, Herbst JH, Coury-Doniger P, Painter TM, English G, et al. (2009) Efficacy of an HIV/STI prevention intervention for black men who have sex with men: findings from the Many Men, Many Voices (3MV) project. AIDS Behav 13: $532-544$.

18. Somerville GG, Diaz S, Davis S, Coleman KD, Taveras S (2006) Adapting the popular opinion leader intervention for Latino young migrant men who have sex with men. AIDS Educ Prev 18: 137-148.

19. Toro-Alfonso J, Varas-Díaz N, Andújar-Bello I (2002) Evaluation of an HIVIAIDS prevention intervention targeting Latino gay men and men who have sex with men in Puerto Rico. AIDS Educ Prev 14: 445-456.

20. Zhang H, Wu Z, Zheng Y, Wang J, Zhu J, et al. (2010) A pilot intervention to increase condom use and HIV testing and counseling among men who have sex with men in Anhui, China. J Acquir Immune Defic Syndr 53: S88-92.

21. Lapinski MK, Randall LM, Peterson M, Peterson A, Klein KA (2009) Prevention options for positives: the effects of a health communication intervention for men who have sex with men living with HIVIAIDS. Health Commun 24: 562-571.

22. Mansergh G, Koblin BA, McKirnan DJ, Hudson SM, Flores SA, et al. (2010) An intervention to reduce HIV risk behavior of substance-using men who have sex with men: a two-group randomized trial with a nonrandomized third group. PLoS Med 7: e1000329.

23. Morin SF, Shade SB, Steward WT, Carrico AW, Remien RH, (2008) A behavioural intervention reduces HIV transmissionrisk by promoting sustained serosorting practices among HIV-infected men whohave sex with men. J Acquir Immune Defic Syndr 49: 544-551.

24. Hoff CC, Pals SL, Purcell DW, Parsons JT, Halkitis PN, et al. (2006) Examining the role of partner status in an HIV prevention trial targeting HIV-positive gay and bisexual men: the seropositive urban men's intervention trial (SUMIT). AIDS Behav 10: 637-648.

25. Wolitski RJ, Gómez CA, Parsons JT (2005) Effects of a peer-led behavioral intervention to reduce HIV transmission and promote serostatus disclosure among HIV-seropositive gay and bisexual men. AIDS 19: S99-109.

26. Butler RB, Schultz JR, Forsberg AD, Brown LK, Parsons JT, et al. (2003) Promoting safer sex among HIV-positive youth with haemophilia: theory, intervention, and outcome. Haemophilia 9: 214-222.

27. Peacock D, Levack A (2004) The men as partners program in South Africa: Reaching men to end gender-based violence and promote sexual and reproductive health. International Journal of Men's Health 3: 173-188.

28. Kalichman SC, Simbayi LC, Cloete A, Cherry C, Strebel A, et al. (2008) HIV/ AIDS risk reduction and domestic violence prevention intervention for South African men. International Journal of Men's Health 7: 255-273. 
Citation: Jbilou J, Robertson SS, Jazebizadeh H, Gallant L, Robinson M, et al. (2013) Men-centered Approaches for Primary and Secondary Prevention of HIVIAIDS: A Scoping Review of Effective Interventions. J AIDS Clin Res 4: 257. doi: 10.4172/2155-6113.1000257

29. Wolitski RJ (2006) Relative efficacy of a multisession sexual risk-reduction intervention for young men released from prisons in 4 states. Am $\mathrm{J}$ Public Health 96: 1854-1861.

30. Parsons JT, Huszti HC, Crudder SO, Rich L, Mendoza J (2000) Maintenance of safer sexual behaviours: evaluation of a theory-based intervention for HIV seropositive men with haemophilia and their female partners. Haemophilia 6: 181-190.

31. Aggarwal AK, Duggal M (2004) Knowledge of men and women about reproductive tract infections and AIDS in a rural area of north India: impact of a community-based intervention. J Health Popul Nutr 22: 413-419.

32. Kegeles SM, Rebchook G, Pollack L, Huebner D, Tebbetts S, et al. (2012) An intervention to help community-based organizations implement an evidencebased HIV prevention intervention: the Mpowerment Project technology exchange system. Am J Community Psychol 49: 182-198.

33. Ugarte Guevara WJ, Valladares Cardoza E, Essén B (2012) Sexuality and risk behavior among men who have sex with men in León, Nicaragua: a mixed methods approach. J Sex Med 9: 1634-1648.

34. Kubicek K, Carpineto J, McDavitt B, Weiss G, Kipke MD (2011) Use and perceptions of the internet for sexual information and partners: a study of young men who have sex with men. Arch Sex Behav 40: 803-816.

35. Mustanski B, Lyons T, Garcia SC (2011) Internet use and sexual health of young men who have sex with men: a mixed-methods study. Arch Sex Behav 40: $289-300$.

36. Njau B, Watt MH, Ostermann J, Manongi R, Sikkema KJ (2012) Perceived acceptability of home-based couples voluntary HIV counseling and testing in Northern Tanzania. AIDS Care 24: 413-419.

37. Saberi P, Gamarel KE, Neilands TB, Comfort M, Sheon N, et al. (2012) Ambiguity, ambivalence, and apprehensions of taking HIV-1 pre-exposure prophylaxis among male couples in San Francisco: a mixed methods study. PLoS One 7: e50061.

38. Dilley JW, Woods WJ, Sabatino J, Lihatsh T, Adler B, et al. (2002) Changing sexual behaviour among gay male repeat testers for HIV: A randomized, controlled trial of a single-session intervention. J Acquir Immune Defic Syndr 30: 177-186

39. Exner TM, Mantell JE, Adeokun LA, Udoh IA, Ladipo OA, et al. (2009) Mobilizing men as partners: the results of an intervention to increase dual protection among Nigerian men. Health Educ Res 24: 846-854.

40. Wiktor SZ, Abouya L, Angoran H, McFarland J, Sassan-Morokro M, et al. (2004) Effect of an HIV counseling and testing program on AIDS-related knowledge and practices in tuberculosis clinics in Abidjan, Côte d'Ivoire. Int J Tuberc Lung Dis 8: $445-450$.

41. Rotheram-Borus MJ, Lee MB, Murphy DA, Futterman D, Duan N, et al. (2001) Efficacy of a preventive intervention for youths living with HIV. Am J Public Health 91: 400-405.

42. Chesney MA, Chambers DB, Taylor JM, Johnson LM, Folkman S (2003) Coping effectiveness training for men living with HIV: Results from a randomized clinical trial testing a group-based intervention. Psychosom Med 65: 1038-1046.

43. Chernoff RA, Davison GC (2005) An evaluation of a brief HIVIAIDS prevention intervention for college students using normative feedback and goal setting. AIDS Educ Prev 17: 91-104.

44. Barss P, Grivna M, Ganczak M, Bernsen R, Al-Maskari F, et al. (2009) Effects of a rapid peer-based HIVIAIDS educational intervention on knowledge and attitudes of high school students in a high-income Arab country. J Acquir Immune Defic Syndr 52: 86-98.

45. Caron F, Godin G, Otis J, Lambert LD (2004) Evaluation of a theoretically based AIDS/STD peer education program on postponing sexual intercourse and on condom use among adolescents attending high school. Health Educ Res 19: 185-197.

46. Siegel DM, Aten MJ, Enaharo M (2001) Long-term effects of a middle schooland high school-based human immunodeficiency virus sexual risk prevention intervention. Arch Pediatr Adolesc Med 155: 1117-1126.
47. Walker D, Gutierrez JP, Torres P, Bertozzi SM (2006) HIV prevention in Mexican schools: Prospective randomized evaluation of intervention. British Medical Journal 332: 1189-1192.

48. Adshead F, Thorpe A (2008) Men's health and the workplace. Journal of Men's Health 5: 118-124.

49. Boyer CB, Shafer MA, Shaffer RA, Brodine SK, Ito SI, et al. (2001) Prevention of sexually transmitted diseases and HIV in young military men: Evaluation of a cognitive-behavioural skills-building intervention. Sex Transm Dis 28: 349-355.

50. Bing EG, Cheng KG, Ortiz DJ, Ovalle-Bahamón RE, Ernesto F, et al. (2008) Evaluation of a prevention intervention to reduce HIV Risk among Angolan soldiers. AIDS Behav 12: 384-395.

51. Leonard L, Ndiaye I, Kapadia A, Eisen G, Diop O, et al. (2000) HIV prevention among male clients of female sex workers in Kaolack, Senegal: results of a peer education program. AIDS Educ Prev 12: 21-37.

52. Van der Borght SF, Schim van der Loeff MF, Clevenbergh P, Kabarega JP Kamo E, et al. (2010) Long-term voluntary counseling and testing (VCT) uptake dynamics in a multicountry HIV workplace program in sub-Saharan Africa. AIDS Care 22: 195-205.

53. Banks I (2001) No man's land: men, illness, and the NHS. BMJ 323: 1058-1060

54. Blas MM, Alva IE, Carcamo CP, Cabello R, Goodreau SM, et al. (2010) Effect of an online video-based intervention to increase HIV testing in men who have sex with men in Peru. PLoS One 5: e10448.

55. Bowen AM, Horvath K, Williams ML (2007) A randomized control trial of Internetdelivered HIV prevention targeting rural MSM. Health Educ Res 22: 120-127.

56. Read SJ, Miller LC, Appleby PR, Nwosu ME, Reynaldo S, et al. (2006) Socially optimized learning in a virtual environment: Reducing risky sexual behaviour among men who have sex with men. Human Communication Research 32: 1-34.

57. Picciano JF (2001) A telephone based brief intervention using motivational enhancement to facilitate HIV risk reduction among MSM: A pilot study. AIDS and Behaviour 5: 251-262.

58. Puccio JA, Belzer M, Olson J, Martinez M, Salata C, et al. (2006) The use of cell phone reminder calls for assisting HIV- infected adolescents and young adults to adhere to highly active antiretroviral therapy: A pilot study. AIDS Patient Care STDS 20: 438-444

59. Carroll C, Lloyd-Jones M, Cooke J, Owen J (2012) Reasons for the use and non-use of school sexual health services: a systematic review of young people's views. J Public Health (Oxf) 34: 403-410.

60. Hirshfield S, Chiasson MA, Joseph H, Scheinmann R, Johnson WD, et al. (2012) An online randomized controlled trial evaluating HIV prevention digita media interventions for men who have sex with men. PLoS One 7: e46252.

61. Brown TL, Alderson KG (2010) Sexual identity and heterosexual male students' usage of homosexual insults: An exploratory study. The Canadian Journal of Human Sexuality 19: 27-42.

62. Oliffe JL, Frank, B, McCreary DR, Tremblay G (2010) Men's Health in Canada: A 2010 update. Journal of Men's Health 7: 189-192.

63. Robertson S, Galdas PM, McCreary DR, Oliffe J, Tremblay G (2009) Men's health promotion in Canada: Current context and future direction. Health Education Journal 68: 266-272.

64. Bogart LM, Wagner GJ, Mutchler MG, Risley B, McDavitt BW, et al. (2012) Community HIV treatment advocacy programs may support treatment adherence. AIDS Educ Prev 24: 1-14.

65. Landolt NK, Phanuphak N, Pinyakorn S, Lakhonphon S, Khongpetch C, et al (2012) Sexual life, options for contraception and intention for conception in HIVpositive people on successful antiretroviral therapy in Thailand. AIDS Care 24: 897-904.

66. Ngongo PB, Priddy F, Park H, Becker J, Bender B, et al. (2012) Developing standards of care for HIV prevention research in developing countries - a case study of 10 research centers in Eastern and Southern Africa. AIDS Care 24: 1277-1289. 